\title{
Girl Power in Cashore’s Graceling
}

\author{
Suryo Tri Saksono, Syarifah, SS \\ Universitas Trunojoyo Madura, Madura, Indonesia
}

\begin{abstract}
Girl Power in Cashore's Graceling is the title of this study. This study uses radical feminism as the theory, because the main character, Katsa, is the portrait of radical feminist. Katsa breaks the traditional gender roles and patriarchal ideology which dismiss and underestimate women as the inferior and subordinate from men dominance. Katsa as the main character is described as a woman who breaks the traditional gender roles by her extraordinary hobbies and capabilities, such as fighting, and killing. She also portrays radical-libertarian feminist who is showed by her principle and commitment on marriage, those are her refusal on marriage and her objection to have children.
\end{abstract}

Keywords: feminist criticism, radical feminism, radical-libertarian feminist

\section{Introduction}

Normally, the patriarchal ideology works to keep women and men in traditional gender roles and thereby maintain male dominance (Tyson, 1999). Patriarchal recognizes women as the inferior and men as the dominance. Nowadays, as a way to protest this condition, women raise their thought and their ideas then it is poured into beautiful works.

In addition, nowadays there are many women who produce beautiful works based on their thought. One of them is Virginia Woolf. She is regarded as a feminist author. She draws her thinking and ideas into beautiful and critical works, such as Mrs. Dalloway (1925) and A Room of One's Own (1929). Those great works tell feminism and lesbian. Woolf's A Room of One's Own was a work which is criticized by male authors, and a new model for female identity.

Moreover, Graceling (2008) is one of the most popular novels which describe radical-libertarian feminist which is portrayed by the main character, Katsa. It describes about woman who has the extraordinary hobbies and capabilities which break the traditional gender roles. It also describes about Katsa who is portrait of radicallibertarian feminist because of her principle and commitment on marriage.

Kristin Cashore is an American fantasy author, which her debut novel is Graceling. Cashore is a daydreamer woman as mentioned in her biography. Her novels grew from her daydreams (Cashore, 2008). Because of her uniqueness hobby and also her highest imagination, her work got some praises. Cashore can mix and combine several genres such as fantasy, romance, also adventure into her work, Graceling.

\section{Review of Theory}

\section{Feminist Criticism}

Tyson (1999) states that feminist criticism examines the ways in which literature (and other cultural

Suryo Tri Saksono, Ph.D., English Department, Universitas Trunojoyo Madura.

Syarifah, SS, Freelance English Teacher, English Department, Universitas Trunojoyo Madura. 
productions), reinforces or undermines the economic, political, social, and psychological oppression of women. It means that feminist criticism describes the oppression toward the women in some position and field such as economic, political, social, and also psychological. Feminist criticism tries to reform the traditional gender roles which underestimate women from men.

Patriarch cast women as a symbol of weakness, modesty, and coward. According to patriarchal concept, feminists are not able to success in their business. They are not allowed to explore their opinion, idea in many spheres. It means that feminist is considered as inferior rather than superior human beings (Tyson, 1999). Besides, Patriarchal concepts also assume that women are the subject of protection rather than the object of the protection. They also considered feminists as submission. They encourage feminists to tolerate familial abuse, and wait patiently for men rescuing. Then, marriage is the only desirable reward for right decision to protect feminists for dangerous, as Cinderella's story which is criticized by feminists (Tyson, 1999). It can be concluded that patriarchal and traditional gender roles consider women as the object of protection and men as the subject of protection.

In addition, in every domain where patriarchy reigns, women are marginalized, defined into the others, such as excluding women from equal access to leadership and decision-making positions (in the family as well as in politics, academia, and the corporate world), paying men higher wages than women for doing the same job (Tyson, 1999). Tong (2009) also states that women in United States are pushed into the specific jobs like nurse, teaching, and childcare. They are taken away from jobs in business, science, technology, engineering, and mathematics. It can be described that patriarchal ideology and traditional gender roles keep women in particular positions. They are inferior and men as the superior.

Otherwise, according to Hannam (2007), feminism is a cultural as well as a political movement. It changes the way women think and feel and affect how women and men live their lives and interpret the world. It means that feminism changes the women's way of thinking and their feeling, and then it changes their way to interpret the world. Feminism makes their thought develop and be modern. So, the women can be more active rather than passive. They can also be as what they want. They can handle some positions which are previously only men can handle. Women are not only in the house, care their children and obey their husband as the traditional gender roles but also find a job which they want.

Besides Marry Wollstonecraft in Hannam (2007) states that if women are given the same educational opportunities as men they would become enlightened citizens, rational mothers, and if single, they will more able to find employment. Marry's powerful message changes women characters and reforms the traditional gender roles. Moreover, women should also be given the opportunity and the chance in some positions such as economical, educational, political field, to explore their idea and opinion, so they can be more active, rational, and they will more able to find job.

\section{Radical Feminism}

Radical feminism analyzes the relationship between social inequality and sexual difference; the domination of women by men is seen to provide the foundation of social inequality, and the sexual oppression of women is seen to underlie the economic, cultural and social subordination of women. (Madsen, 2000, pp. 152-153)

Those statements describes that radical feminism examines the relationship between the inequality of social and sexuality. These differences arise from the differences of women and men positions in some fields, 
such as economical, and social cultural. Furthermore, according to radical feminist the domination of women by men are caused because of the difference sexuality.

In addition, Tong (2009) reinforces that radical-libertarian feminists rejected the patriarchal assumption toward gender and sex. They state that patriarchal roles concept toward gender and sex must be reformed. There must be a separation between gender (masculine or feminine) and sex (male or female) because patriarch uses clumsy and rigid gender roles to keep women as passive and men as the active. According to Oxford dictionary masculine means having the qualities or appearance considered to be typical of or appropriate for men (Hornby, 1995). Meanwhile, feminine means having the qualities or appearance considered characteristic of women (Hornby, 1995). Besides, male means one of the sexes that do not give birth to babies (Hornby, 1995). Otherwise, female means one of the sexes that can give birth to children or produce eggs (Hornby, 1995). It can be concluded that female and male refer to the sex. Meanwhile, male and female reflect to characteristic and behavior.

Radical feminism has two branches which are radical-libertarian feminist and radical-cultural feminist. These branches have different ideas and argument toward sexism.

The first branch of radical feminist is radical-libertarian feminists, who claim that biological motherhood drains women physically and psychologically. Women should be free to use their old-controlling and the new reproduction-assisting technologies by their own way and their terms. They also argue that women are free for unwanted pregnancies or they can have children when they want them (premenopausally or postmenopausally). They should be free how they want them (in their own womb or the other women), and with whom they want them (a man, woman, or alone) (Tong, 2009). It means that women can control their reproduction biology. They are allowed to be mothers or singles. They are free to choose their couple, with women, men, or alone. It is strengthens by Mirro and Rogers (2007) statement that Radical-Libertarian feminists like to violate sexual norms and believe that women should control every aspect of their sexuality. Women should control both of their sexuality and reproduction.

Related to the explanation above, Echols (2009) delivers her ideas by his statement below:

Just because a woman is biologically a female does not mean she is destined to exhibit only feminine characteristics. Women can be masculine as well as feminine. They can choose their gender roles and identities, mixing and matching them at will. (p. 50)

Those quotations mean that although women are biologically female but they can destine and free to live as masculine or feminine characteristic depend on their own choice. They also can mix them, become feminine and masculine, and live with both of them, if they want it. Women can be as masculine as men. They are allowed to express their style as feminine or masculine depend on their willingness.

In line with those statements, Shulamith Firestone, another radical-libertarian feminist, states that men and women would be encouraged to mix and match feminine and masculine traits and behaviors in whatever combination they wished (Tong, 2009). They can combine between feminine and masculine as they want. Instead, Firestone believes that women and men would be encouraged to mix and match feminine and masculine traits and behaviors in whatever combination they wished. In short, everyone is allowed to be androgynous person in the world. Meanwhile, Androgyny means having both and female characteristic (Hornby, 1995). In addition, Mirro and Rogers (2007) state androgyny means to have both male and female characteristics. So, it can be concluded that everyone can be masculine and feminine at the same time as they wish. 
The last branch of radical feminist is radical-cultural feminist which rejects the radical-libertarian feminist opinion. They deliver their thought by this statement below:

Radical-cultural feminists expressed the view that it is better for women to be strictly female/feminine. Women, they said, should not try to be like men. On the contrary, they should try to be more like women, emphasizing the values and virtues culturally associated with women ("interdependence, community, connection, sharing, emotion, body, trust, absence of hierarchy, nature, immanence, process, joy, peace and life”). (Tong, 2009, p. 50)

Radical-cultural feminists have an opposite argument and statement about the sexism. They argue that women should not be like men. Moreover, they should be feminine as their fates. They should try to be more like women as their sex. They should emphasize and support the cultural values and virtues. They should be feminine as the cultural values and virtues which flare up in the large society. Then, women should recognize and emphasize the cultural values and virtues of men as the masculine and stronger than them. Moreover, they argue that for the ideal women they should appreciate the cultural values and virtues among themselves. They should recognize that all of women are female nature, but the influences of the men should make them better.

\section{Discussions}

\section{Katsa's Personality Breaks the Traditional Gender Roles}

Katsa is the main character who has extraordinary hobbies and occupation such as lady fighter, lady killer and protector. Being a lady fighter, lady killer and protector mean that she is strong, aggressive, competitive, and planful which break the traditional gender roles perception about women personalities. Tong (2009) states that women are affectionate, obedient, and responsive to sympathy, and approval, cheerful, kind and friendly human beings.

\section{Katsa as an Extraordinary Woman}

\section{Katsa as a strong woman.}

As the previous explanation, women are considered as weak human being, but Katsa is a different woman. She has an extraordinary power and strength. It is showed by her action in carrying Po's grandfather on her shoulders alone. She can defeat a lion alone. In this novel, her strength is confessed by men in this novel. As traditional gender roles concept is related to men, but in this novel Katsa is described as a strong woman (Tyson, 1999). That is why she is a woman who breaks the traditional gender roles by her extraordinary strength.

Besides, Katsa has an extraordinary stamina. When she fights with Po, she never gets tired. Although, Po hit her for more times, she never feel hurt. Hence, Po confesses her strength and her stamina. In this novel, Katsa is portrayed as strength woman and Po is described as a weak woman, because men are not allowed to confess her pain and their weakness in front of men or even women (Tyson, 1999). But, Po confesses his pain and his weakness in front of Katsa. Po's personality is contradictory to traditional gender roles concept of men characteristics. Otherwise, Katsa's personality is not identical to female characteristic.

\section{Katsa as a woman who likes to fight.}

In the story, Katsa is a woman who is portrayed to have the same capability as men. She is a fighter. She likes fighting very much. She practices it every day. She usually practices her fighting to the prisoners who executed to death. Fighting is her hobby. She can defeat big numbers of her enemies alone. She has a good capability in fighting. Her good capability is confessed by men in this novel. Those characteristics are not reflected to women's characteristics which are stated by Tyson (1999). Generally speaking, Women just stay 
passive and stay calm with their modesty, frailty, and timidity (Tyson, 1999). Otherwise, being a lady fighter means that she is a brave, aggressive, and planful woman. Hence, Katsa is described as a woman who breaks the traditional gender by her personalities.

In addition, she delivers her hobby, fighting, by teaching her friends, Bitterblue, Po, Skye, guards, and the messengers. Almost of her students are men, except Bitterblue. It means that her capability is fighting is better than men around her. By having a particular position, lady fighter, from Middluns means that she is an aggressive, brave, planful, and competitive woman. Those personalities are not identical to female personalities. According to Tyson, female are symbols of gentle, submissive, virginal, and angelic, as traditional gender roles concepts (Tyson, 1999). Because of that, Katsa’s personalities break the traditional gender roles.

In addition, in delivering her hobby, fighting, Katsa always wears trousers and hood. Otherwise, being a woman is not only identified by characteristics but also by appearances. Katsa's appearance does not reflect feminist appearances. Hooks (2000) states that before women's liberation all females young and old were socialized by sexist thinking to believe that our value rested solely on appearance and whether or not we were perceived to be good looking, especially by men. Nowadays, for women who had never been comfortable in dresses and skirts, all these changes were exciting. Today they can appear trivial to females who have been able to freely choose what they want to wear from childhood on (Hooks, 2000). Katsa does not restrict herself by wearing female's clothes as the majority of society assumption. Instead of wearing dress or skirt, Katsa prefers to wear hood and trouser.

\section{Katsa as a woman with a strong killing instinct.}

Katsa has a particular position in Middluns Kingdom. She is a lady killer. Her name is well-known around Middluns and the other kingdoms. So, everybody who meets her will be frightened. She is a cruel lady killer. She was eight years old when she killed her cousin by her bare hand. For the first time, King Randa, her uncle, who knows her capability uses her to be his lady killer. In the end, she rebels King rules and she does what she wants. She will kill someone who will restrict her freedom, even King Randa.

Katsa is described as a woman who likes to fight, because of that she prefers to be a lady killer. It means that Katsa is a cruel, aggressive, planful, and ambitious woman. Those personalities do not relate to traditional gender roles perception about women personalities. According to Tong, traditional gender roles keep women passive ("affectionate, obedient, responsive to sympathy and approval, cheerful, kind and friendly") and men active ("tenacious, aggressive, curious, ambitious, planful, responsible, original and competitive”) (Tong, 2009).

By being a lady killer means that she takes off her feminine characteristics and changes them into masculine. It means that she is a portrait of radical-libertarian feminist who has a freedom to be masculine, feminine characteristic (Tong, 2009). Otherwise, Katsa prefers to be masculine woman rather than feminine woman.

\section{Katsa as a protective woman.}

Generally speaking, women are a portrait of the object of protection and men are the subject of protection (Tong, 1999), but Katsa proves that woman can be a protector as well as man. It can be seen by her action in saving her friends, even her men around her. As an extraordinary woman with an extraordinary strength, Katsa prefers to deliver her strength to be a protective woman. In this novel, her men are described as the object of protection and Katsa is the subject of protection. Her men also confess her as the protector.

Related to the explanation above, Katsa will do everything to protect her friend. It can be seen when she 
protects Bitterblue from her father, King Leck. She climbs the snowy mountain and carries Bitteblue on her shoulders. The author tells in this novel that there is no one can pass and climb that snowy mountain, but Katsa can do that. In this mountain, she fights with lion which wants to attack her and she can defeat it lonely.

Being a protector, means she breaks the traditional gender roles which cast men as rational, strong, protective, and deceive. Meanwhile, traditional gender roles cast women as emotional (irrational), weak, nurturing, and submissive (Tyson, 1999). In this novel Katsa is described as the subject of protection and men as the object of protection.

\section{Katsa as the portrayal of radical-libertarian feminist.}

Katsa is a main character, who portrays the radical feminist by her commitment not to marry and have any children. As it has been already mentioned in the previous chapter-radical-libertarian feminist concept that women have their freedom to marry men or be a single woman. They also have their freedom to have babies or unwanted them (Tong, 2009).

\section{Katsa's Refusal on Marriage}

In the majority of the world's societies, marriage put women in a position subordinate to their husbands. Marriage gives husbands great power over their wives and gives fathers greater power over their children (Wishner-Hanks, 2004). It means that, marriage will keep women as the subordinate and men as the super ordinate. Husband will hold the greatest power among children and wife. Because of that, she refuses to marry man.

Besides, she never wants to be a wife. Being a wife, means that she has to lay in a bed with her husband, bear baby. In her mind, being a wife means that she has to be a good wife, caring her husband, her children. She should be a good mother for her children and should service her in his bed. She is afraid to lose her freedom of life. She does not want to be inferior. It is in line with Tong's (2009) statement that radical feminists claim men's control of both women's sexuality and reproductive, their self-identity, and their self-esteem are the most fundamental oppression. In her mind, a husband will oppress his wife's sexuality and reproduction. The husband will control her freedom of life. Because of those reasons, she refuses to be a wife. Hence, she is a portrait of radical-libertarian feminist.

Although, she loves Po very much but she will never have him. Katsa wants to go away from Po's side. She does not belong to someone. In her mind, being a wife, she will do everything what her husband wants. She cannot do that, because she wants to be free. Being a wife, she must send children and obey her husband's control, both in her sexuality and reproduction. Her reason of refusal on marriage is in line with Tong's (2009) statement that the men's control toward women both in reproduction and sex is the most fundamental oppression in their life.

In addition, she wants to be alone without the restriction or some roles of someone else. Being a wife, she must be a good wife who must obey and respect her husband's rules. She must respect her role as a wife. Although, if Po will give her a freedom, but that freedom will not fully be her own, because she is not a single woman. If she becomes a wife, she will make promises for her future. She has to be a good wife for her husband. Katsa believes that if she becomes Po's wife she will not have her freedom, even Po gives it. She thinks that love will break her freedom. So, she does not want to be a wife. As the explanation in the previous chapter, radical feminists allow women to express their sexual intention with men, women, or with themselves (Tong, 2009). Here, Katsa chooses to be a single woman. She still holds her principle to be a single woman tightly. Hence, Katsa is a portrait of radical feminist who wants to be free with her own decision. 
Shortly, Katsa will not ever marry men because she wants to be freedom without any restriction. According Katsa, being a wife means she must be a good wife who must obey and respect her husband's roles and rules, nurture her children well. Hence, Katsa is a portrait of radical feminist who wants to hold her principle as a woman tightly. Because of being a wife, she will be an inferior and subordinate and her husband will be a superior and super-ordinate.

\section{Katsa's Objection to Have Children.}

Katsa does not want to be a mother. Even, she never and will not wish having children. Thinking of children makes her panic. Her principle in objection to have children relates to the radical-libertarian feminist who give women freedom to have or not have children. Here, Katsa is the portrait of radical feminist because of her strong principle. Besides that, her unwillingness to have children related to Tong argument that woman are allowed for bearing children (premenopausally or postmenopausally) or objecting them (Tong, 2009). Hence, Katsa is the portrayal of radical feminist.

In her mind, being wife and having children are the affront, because she will be his nurturing and submissive woman. She has to be a good wife who will stay at home and preserves Giddon's children. As Tong's (2009) statement that women are free to control their reproduction as they want. Here, Katsa chooses to be a single woman without children, husband, even family. Instead of being a wife and a mother, Katsa prefers to be a single woman.

Related to the explanation above, Katsa does not want to be Raffin's, prince of Middluns, wife. She knows that if she becomes his wife, automatically she has to be a Queen of Middluns. She has to be a mother for his crown price or princess. She does not want to have them. Of course, she has to be a good woman. Hooks (2000) states that feminists focus on reproductive rights is needed to protect and sustain our freedom. Katsa is a portrait of feminist who wants to be free for controlling her reproductive by her objection to have children.

Shortly, Katsa's principle relates to the radical-libertarian feminist who gives women freedom to have or have not children. Here, Katsa is the portrait of radical feminist because of her strong principle. She just wants to do what she wants without someone's restriction.

\section{Conclusions}

After analyzing Kristin Cashore's Graceling by using radical feminist criticism, it can be concluded that the main character, Katsa, is a portrait of radical-libertarian feminist. It is known by her personalities which are so different from traditional gender roles concept about women. She has extraordinary occupations which are always related to the men normally, they are killer, fighter, and protector. She also has an extraordinary strength, so she prefers to be lady killer and lady fighter. Here, Katsa tries to prove that women can be everything that they want without paying attention to her gender and sexuality. Here, Katsa prefers to be masculine woman. It reflects the radical-libertarian feminist concept that women have their freedom to be masculine or feminine or mix them.

Katsa also has the strong principle and commitment. She will not ever marry men. Even with her beloved man, Po. Although, Po promises her to give her freedom if she become his wife, but Katsa always refuses it. She thinks that even he gives her freedom she still cannot do everything as she wants because she is a wife. So that, she still holds her commitment.

Besides that, Katsa also never wants to be a mother. She will be panic if she thinks about babies. She 
cannot imagine if she will be a mother. She thinks that her freedom will be restricted by children by her side.

So that she makes decision to be a single woman, without husband and children by her side.

\section{References}

Benhabib, S., \& Cornell, D. (1987). Feminism as critique. Minneapolis: University of Minnesota Press.

Cashore, K. (2008). Graceling. New York: Graphia Boston New York.

Denzin, N. K., \& Lincoln, Y. S. (2005). Handbook of qualitative research. Thousand Oaks: Sage Publications, Inc..

Dickens, P. (2010). Exploring anarcha-feminism: Marriage and freedom. Retrieved from http://propertyistheft.wordpress.com/2010/05/04/exploring-anarcha-feminism-marriage-and-freedom/

Echols, A. (2009). Women's and gender studies. New Brunswick: Rutgers University Press.

Ferguson, A., Philipson, I., Diamond, I., Quinby, L., Vance, C. S., \& Snitow, A. B. (1984). Forum: The feminist sexuality debates. Retrieved from http://www.kmu.edu.tw/ gigs/enrollment/doc/The_Feminist_Sexuality_Debates.pdf

Hannam, J. (2007). Feminism: A short history of a big idea. London: Pearson Longman.

Hook, B. (2000). Feminism is for everybody: Passionate politics. Cambridge: South End Press.

Hornby, A. S. (1995). Oxford advanced learners dictionary international. London: Oxford University Press.

Madsen, D. L. (2000). Feminist theory and literary practice. London: Pluto Press.

Meade, T. A., \& Wishner-Hanks, M. E. (2004). A companion to gender history. London: Blackwell Publishing Ltd..

Mirro, T., \& Rogers, D. (2007). Absolutely “radical” pornography. Retrieved from http://www.montclair.edu/media/montclairedu/equityanddiversity/Student.pdf

Octavia, A. (2000). A study on the elements of feminism as seen through Hester's characters in Nathaniel Hawthorne's The Scarlet Letter (Master thesis, Surabaya: Universitas Kristen Petra Publisher).

Rohemah, S. (2011). The manifestation of feminism (Master thesis, University Trunojoyo Madura).

Tong, R. (2009). Feminist thought (3rd ed.). New York: West View Press.

Tyson, L. (1999). Critical theory today. New York \& London: Garland Publishing, Inc..

Walters, M. (2005). Feminism: A very short introduction. New York: Oxford University Press Inc..

WU, Y. J. (2012). Fatal attraction for teens-An analysis of Kristin Cashore's Graceling. Retrieved from http://www.shs.edu.tw/works/essay/2012/03/2012033017512237.pdf 